\title{
Attitudes Towards the Practice of Rational Drug Use by Practitioners and Factors Influencing Drug Writing
}

\section{Pratisyen Hekimlerin Akılcı İlaç Kullanımı Uygulaması Konusunda Tutumları ve İlaç Yazımlarını Şekillendiren Faktörler}

\author{
Erkay Nacar ${ }^{l}$, Burak Mete $^{I}$, Çiğdem Tekin ${ }^{* 2}$, Erkan Pehlivan ${ }^{1}$, Deniz Bektaş ${ }^{1}$
}

\begin{abstract}
Introduction: The purpose of this research is to investigate the attitudes of practitioners working in different departments and sectors on rational drug use (RDU) and the factors influencing prescribing. Method: The study was conducted with the physicians working in family health centers and hospitals in Malatya province center with face-to-face interviews. The questionnaire was implemented to 132 practitioners. The questionnaire was composed of 12 questions inquiring socio-demographic features, rational use of drugs and factors influencing prescription. Results: Of the participants 66,7\% had 10 years or more of professional experience and 89,4\% stated that they prescribed analgesics and derivatives, $8,3 \%$ antibiotics. More than half of the physicians stated that post-graduate education and promotions of drug companies influence their prescribing drugs. Conclusion: It has been reached that physicians' writing of medicines is influenced by the presentation of pharmaceutical companies and in drugs election all of the rational drug selection criteira are not given the same importance by physicians. Physicians were detected to be influenced from the promotions of drug companies but all criteria of rational drug use were not cared equally.
\end{abstract}

Key Words: Drug prescription, general practitioner, efficiency

ÖZET

Giriş: $\mathrm{Bu}$ araştırmanın amacı farklı birimlerde ve sektörlerde çalışan pratisyen hekimlerin akılcı ilaç kullanımı (AİK) konusunda tutumları ve reçete yazımında etkili olan faktörlerin saptanmasıdır. Yöntem: Çalışma Malatya il merkezinde aile sağlığı merkezleri ve hastanelerde çalışan hekimler ile yüz yüze görüşülerek yapılmıştır. Anket formları 132 hekim tarafindan doldurulmuştur. Ankette sosyo-demografik özellikler, hekimlerin AİK ve reçete yazmasını etkileyen faktörleri belirlemeyi amaçlayan 12 soru sorulmuştur. Bulgular: Çalışmaya katılan pratisyen hekimlerin \% 66,7'si 10 yıl ve üzerinde mesleki tecrübeye sahipti. Hekimlere en çok reçete ettikleri ilaçlar sorulduğunda; \%89,4’ü ağrı kesici ve türevlerini, \%8,3 antibiyotik gruplarını reçete ettiklerini ifade etmişlerdir. Hekimlerin yarısından fazlası mezuniyet sonrası okuma ve ilaç firma tanıtımlarının reçete yazımını şekillendirdiğini ifade etmişlerdir. Sonuç: Hekimlerin ilaç yazımlarının, ilaç firma tanıtımlarından etkilediği ve ilaç seçiminde akılcı ilaç kriterlerinin hepsine aynı önemde dikkat edilmediği sonucuna ulaşılmıştır.

Anahtar kelimeler: İlaç reçetesi, pratisyen hekim, etkinlik

Received Date / Geliş tarihi: 16.11.2017, Accepted Date / Kabul tarihi: 17.05.2018

${ }^{1}$ İnönü Üniversitesi Tıp Fakültesi Halk Sağlığı A.D. Malatya/TÜRKIYE

${ }^{2}$ İnönü Üniversitesi Sağlık Hizmetleri Meslek Yüksekokulu Hemşirelik ve Bakım Hizmetleri Bölümü MalatyalTÜRKIYE

*Address for Correspondence / Yazışma Adresi: Çiğdem Tekin, İnönü Üniversitesi Sağlık Hizmetleri Meslek Yüksekokulu Hemşirelik ve Bakım Hizmetleri Bölümü MalatyalTÜRKIYYE E-mail: cigdemmoz@ gmail.com

Nacar E, Mete B, Tekin Ç, Pehlivan E, Bektaş D. Pratisyen Hekimlerin Akılıı İlaç Kullanımı Uygulaması Konusunda Tutumları ve İlaç Yazımlarını Şekillendiren Faktörler. TJFMPC, 2018;12(3): 178-185. DOI: 10.21763/tjfmpc.452461 


\section{GİRIŞ}

1985 yılında Nairobi’de akılcı ilaç kullanımı (AİK) ile ilgili yapılan toplantıda AİK kişilerin klinik bulgularına ve bireysel özelliklerine göre uygun ilacı, uygun süre ve dozajda, en düşük fiyata ve kolayca sağlayabilmeleri olarak tanımlanmıştır. ${ }^{1} \mathrm{Bu}$ açıdan değerlendirildiğinde AIKK için ilk adım hastaya doğru tanı konulmasıdır. Daha sonraki aşama ise hastanın şikayetlerine, hastalığının nedenine etkili, hastaya en az yan etkisi ve maliyeti olan ilacin seçilip, optimum doz ve sürede kullanılmasıdır. ${ }^{2}$

Bütün dünyada ilaç tedavi maliyetinin yaklaşık 859 milyar Amerikan doları olduğu görülmüştür. Bütün dünyada ilaç harcamalarına ayrılan payın toplam gayri safi yurtiçi hasılanın ortalama $\% 1,52$ 'si olduğu görülürken, total sağlık harcamaları içindeki payı ise yaklaşık olarak \%24,9'dur. ${ }^{3}$ Türkiye'de Sağlık Bakanlığı'na bağlı bir genel müdürlük tarafından OECD hesaplama metodu kullanılarak hesaplama yapılan bir raporun sonuçlarına göre 1999 yılında yaklaşık 5 milyar TL düzeyinde olan toplam sağlık harcamasının, 2011 y1lında 76 milyar TL'ye düzeyine yükseldiği görülmüştür. Sağlık için ayrılan payın toplam gayri safi yurtiçi hasıla içindeki payı 1999 yılında \%4,8 iken, 2015 yılında bu oranın \%5,4'e çıktığını saptamıştır. ${ }^{4}$

2015 yılında Sağlık Bakanlığı tarafından yayınlanan rapora göre tüketilen toplam ilaç kutu sayıs1 2 milyar 112 milyon olarak belirtilmiştir. Aynı raporda yapılan harcamaların yarısından fazlasının ithal ilaçlara yapıldığı belirtilmiştir. ${ }^{5}$

Akılcı olmayan ilaç kullanımı, kişilerin klinik bulguları ve bireysel özellikleri göz önünde bulundurulmadan kişiye uygun olmayan ilacın süre, dozuna ve maliyetine dikkat edilmeden kullanımını ifade etmektedir. Akılcı olmayan ilaç kullanımına örnek olarak şu durumlar gösterilebilir; bir hasta için gerekenden fazla sayıda ilaç yazılması (polifarmasi), hastaya ilaç gerekmediği halde reçete yazılması, uygunsuz antibiyotiğin reçete edilmesi, ilaç kullanım formunun hastaya uygun olmayan şeklinin seçilmesi, bilimsel kılavuzlara uygun olmayan ilaçların reçete edilmesi, tedavi için hasta uyumunun sağlanamaması ve hastaların istekleri doğrultusunda reçete yazılmasıdır. ${ }^{6}$

Akılcı olmayan ilaç kullanımı her yıl çok miktarda ilaç tüketimine ve savurganlığına neden olmaktadır. Bu konu ile ilgili ülkemizde yapılan çalışmalar konunun önemini ortaya koymaktadır. 2006 yılında ilaç israfı ile ilgili yayınlanan bir rapora göre; reçete edilen ilaçların yaklaşık \%60'ınon hiç kullanılmadan miadının dolduğunu, ayrıca eczanelerde satılan ilaçların ortalama \%7'sinin aynı şekilde kullanım süresi dolduğu için çöpe atıldığı gerçeğini gözler önüne sermektedir. Bütün bu israf edilen ilaçların ekonomik maliyetinin yaklaşık 500 milyon dolar olduğu görülmektedir. ${ }^{7}$ Göçgeldi ve ark. tarafından yapılan çalışmada ise katılımcıların yaklaşık üçte ikisinin evlerinde artık ilaç bulunduğu saptanmıştır. ${ }^{8}$ Sosyal Güvenlik Kurumu'nun toplam sağlık harcamaları içinde, ilaç harcamaları payı yaklaşık \%45-50 arasında değişmektedir. ${ }^{9}$ Sağllk hizmeti sunumunda AİK'nin önemi ortadadır. AİK uygulamaları ile hem sağlık hizmet sunumunun etkinliği artmakta hem de ilaç kullanımındaki israfł önlenmektedir. AİK uygulamalarında sorumluluğun büyük kısmı hekimlere düşmektedir. $\mathrm{Bu}$ açıdan değerlendirildiğinde hekimlerin ilaç reçete ederken ilacın etkililiği, yan etkileri ve fiyatı gibi birçok faktörü göz önünde bulundurması gerekmektedir. ${ }^{10}$

Tıp fakültesi mezunları, eğitimleri sırasında AİK ilkelerini yeterince öğrenememe sorunuyla karşılaşmaktadırlar. ${ }^{11}$ Ülkemizde akılcı olmayan ilaç kullanımının, tıp eğitimi ve sonrasındaki eksikliklerden kaynaklandığı görülmüştür. $\mathrm{Bu}$ eksikleri tespit edecek, yapılmış yeterince çalışmaya ulaşılamamıştır ve çalışmalara gerek vardır. Hekimlerin AİK ile ilgili beklentilere ne ölçüde yanıt verdiğini değerlendirmek ve aksaklıkları giderebilmek için öncelikle hekimlerin konuyla ilgili bilgi ve tutumlarının belirlenmesi gerekmektedir.

$\mathrm{Bu}$ araştırmanın amacı farklı birimlerde ve sektörlerde çalışan pratisyen hekimlerin AİK konusunda tutumları ve reçete yazımında etkili olan faktörlerin saptanmasıdır.

\section{YÖNTEM}

Çalışmamız 2016 yılı Temmuz-Ağustos ayları arasında Malatya il merkezinde kamu ve özel sektörde çalışmakta olan pratisyen hekimlerde yapılmıştır. Çalışmanın yapılabilmesi için etik kurul izni alınmıştır (Karar no: 2016\9-21). Çalışmamız kesitsel-tanımlayıcı tipte bir çalışmadır. Çalışmamızın evreni Malatya il merkezindeki 150 aile sağlığ 1 merkezinde, 40 devlet hastanesinde, 13 özel hastanede görevli pratisyenler hekim olmak üzere toplam 203 pratisyen hekimden oluşmaktadır. $\% 95$ güven aralığı ve \%80 güç ile yapılan power analizi hesaplamalarında ulaşılması gereken minimum örneklem büyüklüğü 116 kişi olarak bulunmuştur. Ulaşılan hekim sayısı aile hekimi, devlet hastanesi ve özel hastanede çalışma durumlarına göre tabakalandırılmıştır. Buna göre 92 hekim aile sağlığı merkezlerinden, 30 hekim devlet hastanesinden, 10 hekim ise özel hastanelerden seçilmiş ve seçimler çalışmaya katılmayı kabul eden pratisyen hekimler arasından basit rastgele olarak yapılmıştır. Sonuç olarak çalışma132 hekim 
ile yürütülmüştür. Örnekleme giren kişilerin seçiminden sonra, her bir birime gidilerek hekimlere çalışma hakkında bilgi verilmiş;, bilgilendirilmiş gönüllü olur formu imzalatılmış ve anketi doldurmak isteyenler çalışmaya dahil edilmiştir. Veriler yüz yüze anket uygulaması ile toplanmıştır. Anket uygulama süresi 10 dakika olarak belirlenmiştir. Ankette sosyo-demografik özellikler, hekimlerin günlük baktıkları hasta sayısı, ortalama muayene süresi gibi çalışma koşullarının, reçete yazımını şekillendiren faktörlerin, yaşlılarda çoklu ilaç kullanım durumlarının ve AİK'nin değerlendirildiği (reçete yazımınızı şekillendiren en önemli faktör, reçete yazımı ile ilgili sorun yaşandığında danışılan kişi, AİK kriterlerini ilaç yazarken önem sırasına göre sıralama vb.) toplam 12 soru sorulmuştur. AİK'yi değerlendiren sorular literatürdeki çalışmalardan faydalanarak hazırlanmıştır. AİK'nin değerlendirilmesinde belirlenen dört kriterin (etkinlik, güvenlilik, uygunluk, tedavi maliyeti) her birine eşit önemin verilmesi ilkesi göz önünde bulundurulmuştur. $\mathrm{Bu}$ kriterlerden herhangi birine diğerlerinden daha fazla önem verilmesi akılcı olmayan ilaç kullanımı olarak değerlendirilmiştir. Çalışma grubu olarak pratisyen hekimlerin seçilmesinin nedeni pratisyen hekimlerin hastalarla ilk ve en çok karşılaşan grup olmasidir. $^{12}$

İstatistiksel Analiz: İstatistiksel analizlerde frekans dağılımları ve Ki-kare testi kullanılmıștır. Veriler, IBM SPSS Statistics for Windows paket programı kullanılarak analiz edilmiştir (IBM Corp. Released 2013. IBM SPSS Statistics for Windows, Version 22.0. Armonk, NY: IBM Corp.).

\section{BULGULAR}

Çalışmaya katılan hekimlerin \%72,7'si erkek, $\% 27,3$ 'ü kadındır. Yaş ortalaması 39,9 +-7,4 yıldır. Çalışmaya katılan pratisyen hekimlerin \%10,6's1 3 y1l ve alt1, \%9,8'si 4-6 y1l aras1, \%12,9'su 7-10 y1l aras1, yüzde 66,7'si 10 y1l ve üzerinde mesleki tecrübeye sahiptir. Hekimlerin \%92,4'ü kamuda, \%7,6's1 özel sektörde çalışmaktadır. Kamuda çalışanların \%77,3'ü aile hekimi, \%22,7'si acil hekimidir. Günlük muayene edilen ortalama hasta sayısı açısından bakıldığında ise hekimlerin $\% 12,1$ 'i 30 kişi ve altı, \%53'ü 31-60 arası kişi, \%10,6'sı 61-90 arası kişi, yüzde 24,2'si 90 ve daha fazla kişiyi muayene ettiğini belirtmiştir. Ortalama muayene sürelerine bakıldığında hekimlerin \%33'ü muayene için 1-4 dakika, \% 50,8'i 5-9 dakika, \%15,9'u 10-14 dakika zaman ayırdığını belirtmiştir. Çalışmamızda muayene için 15 dakika ve daha fazla vakit ayıran hekime rastlanmamıştır (Tablo 1).

\begin{tabular}{|l|l|l|}
\begin{tabular}{|l|l|} 
Tablo 1. Sosyo-demografik özellikler ve meslek \\
özelliklerinin dağılımı (N=132)
\end{tabular} \\
\hline Özellikler & $\mathrm{n}$ & $\begin{array}{l}\text { Yüzde } \\
(\%)\end{array}$ \\
\hline Cinsiyet & & \\
\hline Erkek & 96 & 72.7 \\
\hline Kadın & 36 & 27.3 \\
\hline Meslek Yıl & & \\
\hline 3 yıl ve altı & 14 & 10.6 \\
\hline 4-6 yıl & 13 & 9.8 \\
\hline 7-10 yıl & 17 & 12.9 \\
\hline 10 yıl ve üzeri & 88 & 66.7 \\
\hline Çalışın Kurum & & \\
\hline Kamu & 122 & 92.4 \\
\hline Özel & 10 & 7.6 \\
\hline Kamu Alt Grup & & \\
\hline Aile hekimi & 93 & 77.3 \\
\hline Acil hekimi & 30 & 22.7 \\
\hline $\begin{array}{l}\text { Günlük Ortalama Bakılan } \\
\text { Hasta Sayısı }\end{array}$ & & \\
\hline 30 ve altı & 16 & 12.1 \\
\hline 31-60 & 70 & 53 \\
\hline 61-90 & 14 & 10.6 \\
\hline 90 ve üzeri & 32 & 24.2 \\
\hline Ortalama Muayene Süresi & & \\
\hline 1-4 dakika & 44 & 33.3 \\
\hline 5-9 dakika & 67 & 50.8 \\
\hline 10-14 dakika & 21 & 15.9 \\
\hline
\end{tabular}

Hekimlere en çok reçete ettikleri ilaçlar sorulduğunda \%89,4'ü ağrı kesici ve türevlerini, $\% 8,3^{\prime}$ ü antibiyotik türlerini, $\% 1,5$ 'i vitamin ve mineral desteklerini, geri kalan hekimler ise diğer ilaç türlerini reçete ettiklerini ifade etmişlerdir (Tablo 2).

\begin{tabular}{|l|l|l|}
\hline $\begin{array}{l}\text { Tablo 2. Reçete edilen ilaçların } \\
\text { (N=132) }\end{array}$ & dağılımı \\
\hline $\begin{array}{l}\text { En Çok Reçete Edilen İlaç } \\
\text { Grubu }\end{array}$ & $n$ & $\begin{array}{l}\text { Yüzde } \\
(\%)\end{array}$ \\
\hline Ağrı Kesiciler & 118 & 89.4 \\
\hline Antibiyotik & 11 & 8.3 \\
\hline Vitamin ve Mineral desteği & 2 & 1.5 \\
\hline Diğer... & 1 & 0.8 \\
\hline
\end{tabular}

Hekimlere reçete yazarken seçeceği ilaçlarda hangi akılcı ilaç kullanımı kriterlerini dikkate aldı ğ sorulduğunda ve bu dört kriter için en önemliden en az önemliye doğru sıralama yapması istendiğinde \%71,2'si birinci kriter olarak etkinlik, \%15,2'si güvenlilik, \%13,6'ü uygunluk kriterini tercih ederken maliyet kriterine dikkat eden hekime rastlanmamıştır (Tablo 3). 


\begin{tabular}{|l|l|l|}
$\begin{array}{l}\text { Tablo 3. Hekimlerin } \\
\text { kriterlerine verilen } \\
\text { (N=132) }\end{array}$ & $\begin{array}{l}\text { akılcı ilaç kullanımı } \\
\text { cevapların } \\
\text { dağılımı }\end{array}$ \\
\hline İlaç Seçim Kriteri & $\mathrm{n}$ & Yüzde(\%) \\
\hline Etkinlik & 94 & 71.2 \\
\hline Güvenlilik & 20 & 15.2 \\
\hline Uygunluk & 18 & 13.6 \\
\hline Tedavi maliyeti & 0 & 0.0 \\
\hline
\end{tabular}

Reçete yazımını etkileyen en önemli faktör sorulduğunda \%37,9'u mezuniyet sonrası okuma, $\% 19,7$ 'si ilaç firma tanıtımları, \%14,4'ü klinik stajlarda görülen reçeteler, $\% 9,8$ 'i farmakoloji dersleri, \% 11,4'ü meslektaşa danışma, \% 6,8'si hizmet içi eğitimlerin etkilediğini söylemiştir
(Tablo 4). Reçete yazımı ile sorun yaşadığında hekimlerin \%43,9'u ilaç rehberine, \%18,9’u tıp kitaplarına, \%6,1'i ilaç firması tanıtımlarına, $\% 12,1$ 'i uzman hekim görüşüne, \%9,1'i meslektaş görüşüne, \%9,8'i bilimsel yayınlara başvurduğunu söylemiştir. Yaşlı hastalara ilaç yazarken endikasyon dışında dikkat ettikleri kriter sorulduğunda hekimlerin \%46,2'si etkinliğin, $\% 30,3^{\prime} \ddot{\mathrm{u}}$ polifarmasinin, \%17,4'ü hastanın isteğinin, \%3,8'i maliyetin etkilediğini ifade etmiştir.Hekimlerin mesleki ve demografik özelliklere göre akılcı ilaç seçim kriterleri kullanım durumlarına bakıldığında, acil hekimlerinin etkinlik kriterine daha çok dikkat ettiği görülmüştür $(\mathrm{p}=0.007)$. Diğer değişkenler açısından istatistiksel bir fark bulunmamıştır (Tablo 5).

Tablo 4. Reçete yazımını etkileyen faktörlerin dağılımı $(\mathrm{N}=132)$

\begin{tabular}{|l|l|l|}
\hline Reçete yazımınızı etkileyen en önemli faktör & $\begin{array}{l}\text { Yüzde } \\
(\%)\end{array}$ & Sayı \\
\hline Mezuniyet sonrası okuma & 37.9 & 50 \\
\hline İlaç firması tanıtımları & 19.7 & 26 \\
\hline Klinik stajlarda görülen reçeteler & 14.4 & 19 \\
\hline Farmakoloji dersleri & 9.8 & 13 \\
\hline Meslektaşa danışma & 11.4 & 15 \\
\hline Hizmet içi eğitim & 6.8 & 9 \\
\hline
\end{tabular}

Tablo 5. Mesleki ve demografik özelliklere göre akılcı ilaç seçim kriteri kullanım durumu

\begin{tabular}{|c|c|c|}
\hline Özellikler & $\mathrm{n}$ & Yüzde $(\%)$ \\
\hline \multicolumn{3}{|l|}{ Cinsiyet } \\
\hline Erkek & 96 & 72.7 \\
\hline Kadın & 36 & 27.3 \\
\hline \multicolumn{3}{|l|}{ Meslek Yıl } \\
\hline 3 y1l ve alt1 & 14 & 10.6 \\
\hline $4-6$ y1l & 13 & 9.8 \\
\hline $7-10$ y1l & 17 & 12.9 \\
\hline 10 yıl ve üzeri & 88 & 66.7 \\
\hline \multicolumn{3}{|l|}{ Çalışılan Kurum } \\
\hline Kamu & 122 & 92.4 \\
\hline Özel & 10 & 7.6 \\
\hline \multicolumn{3}{|l|}{ Kamu Alt Grup } \\
\hline Aile hekimi & 93 & 77.3 \\
\hline Acil hekimi & 30 & 22.7 \\
\hline \multicolumn{3}{|c|}{ Günlük Ortalama Bakılan Hasta Sayısı } \\
\hline 30 ve alt1 & 16 & 12.1 \\
\hline $31-60$ & 70 & 53 \\
\hline $61-90$ & 14 & 10.6 \\
\hline 90 ve üzeri & 32 & 24.2 \\
\hline \multicolumn{3}{|c|}{ Ortalama Muayene Süresi } \\
\hline 1-4 dakika & 44 & 33.3 \\
\hline 5-9 dakika & 67 & 50.8 \\
\hline 10-14 dakika & 21 & 15.9 \\
\hline
\end{tabular}

P*: Ki kare testi 


\section{TARTIŞMA}

Günlük muayene edilen hasta sayısı açısından bakıldığında çalışmamıza katılan hekimlerin yarısından fazlası 31-60 arasında hastayı muayene ettiğini ifade etmiştir. Mollahaliloğlu'nun 2000 yılında Ankara il merkezinde bulunan sağlık ocaklarında yaptığı çalışmada, hekimlerin \%21,7'si günlük ortalama muayene sayısının 30'un altında olduğunu belirtmiştir. ${ }^{13}$ Aynı çalışmada günde 6090 arası hasta muayene ettiğini belirten hekim oranı \%28,3 olup çalışmamızdan oldukça düşük bulunmuştur. $\mathrm{Bu}$ farkın bölgesel farklılıktan veya çalışmanın yapıldığı yıldaki sağlık sistemi farklılığından kaynaklandığı düşünülmektedir. Aile hekimlerinin iş gücünün değerlendirildiği başka bir çalışmada bizim çalışmamızla benzer olarak, bir aile hekimi bir günde ortalama 60 kişinin poliklinik hizmetini karşıladıklarını belirtmiştir. ${ }^{14}$

Hasta başına ayrılan ortalama muayene sürelerine bakıldığında çalışmamıza katılan hekimlerin yarısı ortalama 5-9 dakika zaman ayırdığını söylemiştir. Vançelik ve ark. yaptığ hekimlerin \%12,5'inin ortalama 1-4 dakika, $\% 40,8$ 'nin 5-9 dakika ve $\% 15,8$ 'inin 15 dakika ve üzerinde zaman ayırdıkları görülmüştür. ${ }^{15}$ Çalışmamızda 15 dakika ve daha fazla zaman ayıran hekime rastlanmamıştır. Mollahaliloğlu'nun yaptığı çalışmada ise çalışmamızı destekler şekilde 15 dakika ve üzerinde muayene eden hekime rastlanmamıştır. ${ }^{13} 2015$ TÜİK verilerine göre hekim başına ortalama düşen kişi sayısı 557 iken hekim başına düşen ortalama müracaat sayısı 4673 kişidir. ${ }^{16} 2016$ yılında Sağlık Bakanlığ 1 tarafından yayınlanan bir raporda 2015 yılında Sağlık Bakanlığı'na bağlı polikliniklere toplamda 306 milyon başvuru olurken, kişi başı ortalama başvuru sayısının 4 olduğu görülmüştür. ${ }^{17}$ Son y1llarda hekimlerin iş yükünün arttığı görülmektedir. Bu durum da hastalara ayrılan zamanın azalmasına neden olmaktadır. Hastaya ayrılan ortalama muayene süresinin en az on dakika olması gerektiği düşünülürse, bizim çalışmamızda pratisyen hekimlerin muayene için hastalara yeterli zaman ayırmadıkları söylenebilir. ${ }^{18}$

Çalışmamızdaki hekimlere en çok reçete ettikleri ilaçlar sorulduğunda en yüksek oranda ağrı kesici ve türevlerini reçete ettiklerini ifade etmişlerdir. Türkiye'deki ilaç tüketimine bakıldığında tüketimin \%50’sini ağrı kesici ilaçlar, soğuk algınlığı ilaçları, antibiyotik, anti-romatizmal ilaçlar ve vitaminler oluşturmaktadır. İlaç tüketiminde ilk sırada \%18,1 ile antibiyotikler varken sırasıyla en çok tüketilen diğer ilaçlar ağrı kesiciler (\%12,3), anti-romatizmal ilaçlar $(\% 11)$ ve soğuk algınlığı ilaçları $(\% 8,4)^{\prime}$ dir. $^{19}$
Sosyal Güvenlik Kurumları'nın toplam sağlık harcamaları içinde ilaç giderlerinin payı yaklaşık \%45-50 arasında seyretmektedir. İlaç harcamalarında en fazla payı antibiyotikler almaktayken bizim çalışmamızda antibiyotiklerin ikinci sırada reçete edildikleri görülmüştür. İlaç harcamaları ile yapılan çalışmada antibiyotiklerin ilaç harcamaları içerisindeki payının \%19,9 olduğu görülmüştür. Bu oran 2003 yılında \%19,9 iken 2010 y1lında \%13,9'a gerilediği görülmüştür. 2010 y1lındaki verilere göre kişi başına ilaç tüketimine harcanan ortalama maliyet 133 dolardır. ${ }^{20}$ Türkiye Ekonomi Politikaları Araştırma Vakfı (TEPAV) tarafından 2012 yılında yayınlanan raporda; sağlık harcamalarındaki artış kaynakları incelendiğinde, artışın \%95'inin tedavi, \%3'ünün ilaç, \%2'sinin ise diğer harcamalar kaynaklı olduğu görülmüştür. ${ }^{21}$ 'İlaç seçiminde en dikkat ettiğiniz kriter hangisidir?' şeklinde sorulduğunda çalışmamıza katılan hekimlerin \%71,2'si birinci kriter olarak etkinlik, \%21,2'si güvenlilik, \%5,3'ü uygunluk, \% 2,3'ü maliyet kriterine dikkat ettiğini ifade etmiştir. Vançelik ve ark. yaptığı araştırmaya katılan hekimler ise reçete yazarken dikkat ettikleri en önemli kriter olarak ilk sirada \%66,4 ile ilacin etkinliği ve $\% 51,3$ ile ilacın güvenliliği olduğunu belirtmişlerdir. ${ }^{15}$ Akıcı ve ark. yaptığı çalışmada da $\% 84,4$ oranında ilk kriter olarak etkinlik bulunmuştur. ${ }^{11}$ Bizim çalışmamızın sonuçları da bu bulguyu desteklemektedir ve bu sonuçlar bizim sonuçlarımızla paralellik göstermektedir. Çalışmamızda ilk sırayı etkinlik alırken diğer üç faktörün güvenlilik, uygunluk ve maliyetin düşük düzeyde veya hiç dikkate alınmaması akılcı olmayan ilaç kullanımına neden olacak bir etken olarak görülmektedir. Ayrıca çalışmamızda akılcı ilaç kullanım kriterinde etkili olması muhtemel değişkenler için yapılan analizde hekimin çalışma biriminin etkili olduğu görülmüştür. Acil hekimlerinin etkililik kriterine aile hekimlerine göre daha çok dikkat ettiği bulunmuştur. Bu farklılığın sebebinin acil hekimlerinin hastalarını genellikle tek sefer görmesi ve mükerrer muayeneyi engellemek için hastanın tedavisinde en etkili ilacı seçmek istemesinden kaynaklandığ düşünülmektedir.

Çalışmamıza katılan hekimlerin reçete yazımını etkileyen en önemli faktör sorulduğunda en yüksek yüzde ile mezuniyet sonrası okuma ve firma tanıtımları olduğu tespit edilmiştir. Vançelik ve ark. yaptığı çalışmada reçete yazımını etkileyen en önemli faktörün \%50,7 ile mezuniyet sonrasında bu konuda okumak olduğu görülmüştür. Aynı çalışmada ikinci en önemli faktörün $\% 40,1$ oranı ile ilaç firması temsilcilerinin tanıtımları olduğu görülmüştür. ${ }^{15} \quad$ Mollahaliloğlu'nun $\quad$ yaptığ 1 çalışmada da benzer şekilde reçete yazımını etkileyen en önemli faktör olarak mezuniyet sonrası okumuş olmak ilk sırada yer alırken, ilaç firması 
tanıtımları ikinci sırada yer almıştır, yine bulgularımıza benzer şekilde hizmet içi eğitim almak ve okulda görülen farmakoloji dersleri son sıralarda yer almıştır. ${ }^{13}$

Türkiye'de 1624 aile hekimi ve uzman hekimle yapılan, ilaç firma tanıtımlarının faaliyetlerine yönelik bakış açılarının değerlendirildiği bir çalışmada aile hekimlerinin \%82'si bu çalışmalardan etkilendiğini/bazen etkilendiğini söylemiştir. Aynı çalışmanın sonuçlarına göre 'tanıtım sonrası reçetelenen ilaçların taşıdığı düşünülen özellikleri' konusunda hekimlerin düşünceleri sorgulandığında, bu ilaçların alternatiflerinden "daha ucuz" $(\% 52,8)$ ve "daha az yan etkili” ( $\% 52,7)$ şeklinde beyan verdikleri görülmüştür. ${ }^{22}$ Özata ve ark. yaptığı çalışmada doktorların reçete yazmasını etkileyen faktörlerin hekimlerin ilacın etkinliği ile ilgili fikirleri, ilaç kullanımı sonrasında gelişecek yan etkiler, yine hekimlerin deneyimleri ve ilaçla ilgili yapılmış çalışmalar ve yayınların önemli olduğu görülmüştür. Bunun yanında, hastaların kapsamında olduğu sosyal güvencesi, hekimlerin eğitimleri dönemindeki hocalarının etkisi ve tavsiyeleri, ilacın piyasadaki ücreti, bilimsel kongreler, ilaç firması temsilcilerinin ziyaretleri, deneyimli meslektaşların tavsiyeleri, hastaların istekleri, ilaçlarla ilgili reklamlar gibi faktörlerin de önemli olduğu görülmüştür. ${ }^{10}$ Şemin'in ve ark. yapmış olduğu çalışmanın sonuçları da bizim çalışmamıza paralel şekilde, reçete etme bilgisinin büyük oranda ilaç firmaları tarafından karşılandığını göstermektedir. ${ }^{23}$ İngiltere'de 25 tıp fakültesinde yapılan ve içinde yeni mezunların da olduğu 2413 öğrencinin katıldığ̀ çalışmanın sonuçları şu şekildedir; öğrencilerin \%74'ü eğitimin etkili ve güvenli ilaç kullanımı için yeterli olmadığı ve \%56'sı da bilgi ve beceriyi ölçmenin yetersiz olduğunu bildirilmiştir. $^{24}$ Bizim çalışmamız ve diğer çalışmalarda da görüldüğü gibi tıp eğitiminin, AİK uygulamaları ve reçete yazımı konularında revizyondan geçmesi ve müfredatta bu konulara ağırlık verilmesi gerektiği görülmektedir.

Çalışmamıza katılan hekimler reçete yazımı ile sorun yaşadığında yarısına yakını ilaç rehberine başvurduğunu, diğer yarısı ise tıp kitaplarına, uzman hekim görüşüne, bilimsel yayınlara, meslektaş görüşüne ve ilaç firması tanıtımlarına başvurduğunu söylemiştir. Pratisyen hekimler üzerinde yapılan bir araştırmaya göre ise çalışmaya katılan hekimlerin yarısından fazlası reçete ettikleri ilaçlarla ilgili bilgi ihtiyaçlarını tam anlamıyla karşılayamadıklarını belirtmiştir. ${ }^{25}$

Tunus'da pratisyen hekimlerin ilaç yazarken başvurdukları en önemli bilgi kaynaklarını araştıran bir çalışmanın sonuçlarına göre; hekimlerin ilk sırada kullandıkları bilgi kaynağı ilaç rehberleri olarak bulunmuştur. Aynı çalışmada doktorların \%30'unun hiçbir bilimsel tıbbi yayını takip etmedikleri ortaya çıkmıştır. ${ }^{26}$

Prosser tarafından yapılan araştırmada da birinci basamakta çalışan doktorların reçete yazımını etkileyen en önemli faktörün ilaç firma tanıtımları olduğu ortaya çıkmıştır. Hekimler arasında, reçete yazımında deneyimli ya da daha bilgili meslektaşa danışmanın ise oldukça düşük oranda olduğu tespit edilmiştir. $^{27}$

Vançelik ve ark. yaptığı çalışmada hekimler reçete yazımı ile sorun yaşadığında, hekimlerin $\% 73,7$ 'si ilaç rehberine, \%48,7'si tıp kitaplarına, $\% 33,6$ 's 1 ilaç firması tanıtımlarına, \%19,1'i uzman hekim görüşüne, \%15,8'i meslektaş görüşüne $\% 9,2$ 'i bilimsel yayınlara başvurduğunu söylemiştir. ${ }^{15}$ Çalışmaların sonuçlarına bakıldığında reçete yazımında en etkili faktörlerin ilaç rehberleri ve ilaç firması tanıtım çalışmaları olduğu görülmektedir. Bilimsel yayınlar ve uzman görüşleri daha az etkili faktörler olarak ortaya çıkmaktadır. $\mathrm{Bu}$ durum akılcı olmayan ilaç uygulamalarının nedenlerini ve boyutlarını ortaya koymada yol gösterici olacaktır.

Çalışmamıza katılan hekimlere yaşlı hastalara ilaç yazarken endikasyon dışında dikkat edilen özelliğin hangisi olduğu sorulduğunda hekimlerin yarısına yakını etkinliğin ve ardından da polifarmasinin ilaç yazımını etkilediğini ifade etmiştir. Bütün dünyada yaşanan demografik değişim ve dönüşüm total nüfusun ve bütün nüfus içindeki yaşlı nüfusun arttığını göstermektedir. ${ }^{28}$ Yaşlı grupta ilaç kullanım sıklığını belirlemek amacıyla yapılan bir çalışmada, huzurevinde kalan yaşlı bireylerin, ilaç kullanım oranının \%94 olduğu ve en çok kullanılan ilaçların, kalp damar sistemi ilaçları ve ağrı kesiciler olduğu saptanmıştır. ${ }^{29}$

Esengen ve ark. tarafından yaşlı insanlar üzerinde yapılan bir çalışmanın sonuçları aynı şekilde yaşlı insanlarda en az bir ilaç kullanım sıklığının yüksek olduğunu ortaya koymuştur. Yaşlı kadınların \%94,3'ünün, erkeklerin ise \%80,4'ünün en az bir adet ilaç kullandığı görülmüştür. Ortalama tüketilen ilaç miktarına bakıldığında ise kadınların günde ortalama 3,59; erkeklerin 2,39 adet ilaç kullandığ 1 tespit edilmiştir. ${ }^{30}$

Diğer bir önemli bir konu ise ilaç kullanımına bağlı olarak meydana gelen beklenmedik ve kişiye zarar veren yan etkidir. İlaç yan etkileri yaşlılar açısından önlenebilir bir konudur. Özellikle meme kanseri, kalp yetmezliği, hipertansiyon ve pnömoni gelişen hastalarda ilaç yan etkileri daha fazla görülmektedir. ${ }^{31}$ Arslan ve ark. tarafindan yapılan bir araştırmada ilaç kullanan her yirmi yaşlı 
hastadan birinde ilaç kullanımına bağlı yan etki geliştiği saptanmıştır. ${ }^{32}$

Yaşlı hastalarda AİK ile ilgili genel ilkeleri şu şekilde sıralayabiliriz: Öncelikle hastaya ilaç tedavisinin gerekli olup olmadığı tespit edilmelidir, hastanın kullandığ 1 başka ilaç veya madde olup olmadığı bilinmeli, hastaya kullanması için verilen ilaçların etkileri iyi bilinmeli, yaşlıların tedaviye başlangıç dozu düşük olmalı, hasta uyumunu artırmak ve kolaylaştırmak için tedavi en basit şekilde planlanmalı ve kontroller düzenli olarak yapılmalıdır. ${ }^{33}$

\section{SONUC}

Sonuç olarak çalışmamızda, hekimler tarafindan, AİK kriterlerinin bir bölümünün çok önemli olarak görülmediği, ilaç yazımında ilacın etkinliğinin en önemli faktör olduğu, diğer faktörlerin önemsenmediği görülmüştür. Literatürdeki diğer çalışmalar gibi bizim çalışmamızda da ilaç firması tanıtımlarının doktorların önemli oranda bilgi kaynağı olduğu, klinik stajların ve farmakoloji derslerinin geri sıralarda olduğu görülmüştür. Ağrı kesici ve türevleri ilaçların birinci basamakta muayene sonrası en çok reçete edilen ilaç olduğu tespit edilmiştir. Yaşlılara ilaç yazımında hekimlerin yaklaşık \%70'inin polifarmasiye dikkat etmediği görülmüştür. Sunulan çalışma, birinci basamakta çalışmakta olan hekimlerin sürekli tıp eğitimi kapsamında AİK ilkeleri konusunda bilgilendirilmelerinin gerekliliğini ortaya koymaktadır. Rasyonel farmakoterapi derslerine ağırlık verilmesi gerektiği önerilebilir. İlaç tüketimindeki yanlış kullanım ve israf azaltılmaya çalışılmalıdır.

\section{Çıkar Çatıșmasıı}

$\mathrm{Bu}$ çalışmanın gerçekleşmesinde herhangi bir kişi ya da kurumla çıkar ilişkisi bulunmamaktadır. Bu makalede, doğrudan veya dolaylı bir ticari bağlantı veya çalışma için destek vererek finansal kaynak sağlayan bir kurum veya kişi bulunmamaktadır. Çalışmanın tüm giderleri araştırmacılar tarafından karşılanmıştır.

\section{KAYNAKLAR}

1. World Health Organization "How to Develop and Implement a National Drug Policy", Geneva,2001.

http://apps.who.int/medicinedocs/pdf/s2283e/s 2283e.pdf (Erişim Tarihi: 08.05.2018).

2. Eşkazan E. Akılcı ilaç kullanımı. İstanbul: İÜ Cerrahpaşa Tıp Fakültesi Sürekli Tıp Eğitimi Yayınları 1999 Ocak;9-20.

3. Lu Y, Hernandez P, Abegunde D, Edejer T. Medicine expenditures. In: The world medicines situation 2011.Geneva:World Health
Organization;

2011.p.6.

http://apps.who.int/medicinedocs/documents/s1 8767en/s18767en.pdf. accessed January 2015.

4. TUİK. Sağlık Harcamaları İstatistikleri Veri Taban1, 2014 Kaynak: http://www.tuik.gov.tr/PreHaberBultenleri.do?i $\mathrm{d}=18853$ (Erișim Tarihi: 15 Şubat 2017).

5. TC Sağlık Bakanlığı Sağlık İstatistikleri Yıllığı $2015 . \quad$ p.168-170. Kaynak: http://www.saglikistatistikleri.gov.tr/dosyalar/S IY_2015.pdf (Erişim Tarihi: 20 Şubat 2017).

6. World Health Organization. WHO Policy perspectives on medicines. Promoting rational use of medicines: core components. Geneva: 2002.p.1.

7. ATO (2006). İlaçta israf raporu. 2006; http://www.atonet.org.tr/turkce/bulten/bulten.p hp3?sira=4388. (Erişim Tarihi: 08.05. 2018).

8. Göçgeldi E, Uçar M, Açıkel CH, Türker T, Hasde M, Ataç A. Evlerde artık ilaç bulunma sıklığı ve ilişkili faktörlerin araştırılması. TAF Prev Med Bull 2009; 8(2):113-18.

9. Ersöz F. Türkiye ile OECD ülkelerinin sağlık düzeyleri ve sağlık harcamalarının analizi. İstatistikçiler Dergisi 2008; 2: 95-104.

10. Özata M, Aslan Ş, Mete M. Rasyonel ilaç kullanımının hasta güvenliğine etkileri: hekimlerin rasyonel ilaç kullanımına etki eden faktörlerin belirlenmesi. Selçuk Üniversitesi Sosyal Bilimler Enstitüsü Dergisi 2008; 20: 529-42.

11. Akıc1 A, Uğurlu M.Ü, Gönüllü N, Oktay Ş, Kalaça S. Pratisyen hekimlerin akılcı ilaç kullanımı konusunda bilgi ve tutumlarının değerlendirilmesi. Sted 2002; 11 (7): 253.

12. Windermeijer F, Laat $E$, Douven R. Pharmaceutical promotion and GP behavior. Health Econ 2006; 15 (5):5-18.

13. Mollahaliloğlu S, Tezcan S. Ankara il merkezinde bulunan sağlık ocaklarından sağlık hizmeti alan hastaların akılcı ilaç kullanımı açısından değerlendirilmesi. 8.Ulusal Halk Sağlığı Kongresi Bildiri Kitabı 23-28 Eylül 2002, Diyarbakır, s.499-501. http://www.dicle.edu.tr/ halks/kongrecdsi.html

14. Tuncal AN, Köroğlu G, Atasoylu G, Sertel M, Tay Z. Manisa ilinde aile hekimlerinin 2011 yılındaki iş yükü ve insan gücünün değerlendirilmesi. Türkiye Aile Hekimliği Dergisi 2014; 18(1): 5-15.

15. Vançelik S, Çalıkoğlu O, Güraksın A, Beyhan E. Pratisyen hekimlerin reçete yazımın şekillendiren faktörler ve akılcı ilaç kullanım kriterlerini önemseme durumları. H.Ü. Eczacılık Fakültesi Dergisi 2006; 26 (2): 6575.

16. TUİK. Hekim sayısı, hekim başına düşen kişi sayısı ve hekim başına hasta müracat sayısı, 2009-2015.

Kaynak: 
http://www.tuik.gov.tr/PreTablo.do?alt_id=109 5 (Erişim Tarihi: 15 Mart 2017).

17. TC Sağlık Bakanlığı Sağlık İstatistikleri Yıllığı 2014. 2002-2015 Sağlık Bakanlığ1- Kişibaş1 müracat ve muayene sayıları. Kaynak: http://dosyasb.saglik.gov.tr/Eklenti/5119,yillikt rpdf.pdf (Erişim Tarihi: 20 Aralık 2016).

18. Northouse P.G, Northouse L.L. Health communication. Strategies for health professionals. Appleton \& Lange, 2th Edition, Washington: 1992. p: 286.

19. Top M, Tarcan M. Türkiye ilaç ekonomisi ve ilaç harcamaları: 1998-2003 dönemi değerlendirmesi. Liberal Düşünce Dergisi 2004; 9(35): 177-200.

20. Pinar N. Drug expenditures in our country. İnönü Üniversitesi Tıp Fakültesi Dergisi, 2012; 19 (1): 59-65.

21. Memiş S. A. Son dönemdeki sağlık harcamalarının analizi. Türkiye Ekonomi Politikaları Araştırma Vakfı (TEPAV) Yayın (201283) 2012.p2.

22. Akıc1 A, Kilboz M.M, Mollahaliloğlu S, Özgülcü Ş, Alkan A. Hekimlerin ilaç tanıtım faaliyetlerine yönelik bakışlarının incelenmesi. Clin Exp Health Sci 2016; 6: 166-172.

23. Şemin S. Sosyal ve ekonomik yönleri ile ilaç. Ankara: TTB Yayınları; 1998. p:45.

24. Heaton A, Webb D.J, Maxwell S.R. Undergraduate preparation for prescribing: the views of 2413 UK medical students and recent graduates. British Journal of Clinical Pharmacology 2008; 66: 128-134.

25. Demirkıran M, Sahin B. Pratisyen hekimlerin ilaç seçimlerini etkileyen faktörlere ilişkin değerlendirmeleri. Hacettepe Sağlık İdaresi Dergisi 2010; 13: 1-28.

26. Ben Abdelaziz A, Harrabi I, Rahmani S, Gaha R, Ghannem H. Attitudes of GPs to pharmaceutical sales representatives in Sousse, in Tunusia. East Mediter Health 2003; 6: 1077.

27. Prosser H, Almond S, Walley T. Influences on GP's decision to prescribe new drugs: the importance of who says what. Fam Pract 2003; 1: 61 .

28. Bıyık A, Özgür G, Özsoy SA, Erefe İ, EmeçUysal A, Özer M, ark. Physical health problems and drug using behaviors related to chronical diseases of the residents living in nursing home. Türk Geriatri Dergisi 2002; 5(2): 68-74.

29. Akıcı A, Kalaça S, Uğurlu ÜM, Çalı Ş, Oktay Ş. Evaluation of rational drug use of general practitioners' in management of elderly patients. Türk Geriatri Dergisi 2001; 4(3): 1005.

30. Esengen Ş, Seçkin Ü, Borman P, Bodur H, Kutsal-Gökçe Y, Yücel M. The assessment of functional cognitive impairment and drug consumption in a group of elderly residents of a nursing home. Türk Geriatri Dergisi 2000; 3(1): 6-10.

31. Arıoğul S. Geriatri ve Gerontoloji. 1.Basım. Ankara: MN Medikal / Nobel Basım Yayın; 2006. p.393-400.

32. Arslan Ş, Atalay A, Gökçe KY. Drug use in elderly. Türk Geriatri Dergisi 2000; 3(2): 5660.

33. Gökçe KY. Aging world. Türk Fiz Tip Rehabilitasyon Dergisi 2006; 52: Özel Ek: A6A11. 